\title{
Posttraumatic stress disorder and posttraumatic growth in HIV-infected patients - the role of coping strategies
}

\section{BACKGROUND}

The purpose of the research was to establish the role of coping strategies in the occurrence of posttraumatic stress disorder (PTSD) and posttraumatic growth (PTG) in HIV-infected individuals.

\section{PARTICIPANTS AND PROCEDURE}

The study was conducted on 25 female and 39 male patients with HIV+ status and applied three questionnaires based on the self-report method. PTSD was assessed with the Impact of Event Scale-Revised (IES-R), PTG with the Posttraumatic Growth Inventory (PTGI), and the Brief version of Coping Orientations to Problems Experienced (Mini-Cope) was used for assessing coping strategies.

\section{RESULTS}

The data showed that half of the examined HIV+ group express a high intensity of PTSD symptoms and a majority of subjects have a medium or high intensity of PTG.
Significant relationships were revealed between avoidance-focused strategies and the negative effects of HIV infection. Surprisingly, active coping strategy positively correlated with overall results of the IES-R and was found to be a predictor of PTSD symptoms. The seeking emotional support strategy was positively correlated with PTG and was considered as the leading predictor of overall PTG. The turning to religion strategy and acceptance were also positively correlated with posttraumatic growth.

\section{CONCLUSIONS}

Avoidance-focused strategies foster PTSD symptoms, while emotion-focused strategies seem to lead to posttraumatic growth.

\section{KEY WORDS}

coping; HIV; posttraumatic stress disorder; posttraumatic growth

organization - 1: Institute of Psychology, University of Lodz, Lodz, Poland · 2: District Psychological and Pedagogical Outpatients Clinic, Piotrków Trybunalski, Poland

authors' Contributions - A: Study design - B: Data collection - C: Statistical analysis - D: Data interpretation .

E: Manuscript preparation · F: Literature search · G: Funds collection

Corresponding AUthor - Prof. Nina Ogińska-Bulik, Institute of Psychology, University of Lodz, 10/12 Smugowa Str., 91-433 Łódź, Poland, e-mail: noginska@uni.lodz.pl

TO CITE this ARTICLE - Ogińska-Bulik, N., \& Kraska, K. (2017). Posttraumatic stress disorder and posttraumatic growth in HIV-infected patients - the role of coping strategies. Health Psychology Report, 5(4), 323-332.

doi: https://doi.org/10.5114/hpr.2017.68017 


\section{BACKGROUND}

In accordance with the World Health Organization (WHO) report, 35.50 million people around the globe live with human immunodeficiency virus (HIV); in Central and Eastern Europe only, the number of HIV-infected patients was 29000 in 2012 (UNAIDS, 2013). The latest report issued by the AIDS National Center in Poland (2012) identified 901 new HIV infections in 2012.

Nina Ogińska-Bulik, Klaudia Kraska

Undoubtedly, being diagnosed with HIV is associated with immense distress, and the person who experiences it feels highly anxious (Martinez, Israelski, Walker, \& Koopman, 2002). Breet, Kagee, and Seedat (2014) stressed that among the many factors that contribute to HIV-infected vulnerability to posttraumatic stress disorder (PTSD), HIV-related stigma stands out as a key catalyst and precursor to interpersonal violence and trauma associated with PTSD.

Rates of HIV-related PTSD range from approximately $15 \%$ to $64 \%$, with up to one third of HIV-infected individuals attributing the onset of PTSD specifically to their HIV diagnosis (Olley, Zeier, Seedat, \& Stein, 2005). Thirty-four percent of HIV-infected patients met the diagnostic criteria of PTSD in the study conducted by Israelski et al. (2007). The fact that PTSD is commonly identified among HIV+ individuals has also been proved by other studies (Sherr et al., 2011; Tedstone \& Tarrier, 2003).

People facing traumatic experiences, apart from absorbing the negative effects exclusively, are able to benefit from the situation as well. It is visible in the emergence of positive changes, which accounts for the phenomenon of posttraumatic growth (Tedeschi \& Calhoun, 1996, 2004). Among people living with HIV/AIDS up to $83 \%$ reported some benefits in the period after the diagnosis (Milam, 2006). The emergence of positive changes among HIV-infected patients and those suffering from AIDS has been observed in several studies (Milam, 2004; Nightingale, Sher, \& Hansen, 2013; Ogińska-Bulik, 2016; Rzeszutek, Oniszczenko, \& Firląg-Burkacka, 2016; Updegraff, Taylor, Kemeny, \& Wyatt, 2002).

Coping strategies constitute a pivotal role in the process of dealing with a traumatic experience. Taylor and Armor's (1996) review shows that people who apply adaptive coping strategies adjust better to the experienced situation. Among the adaptive posttraumatic coping strategies the following stand out: religious/spiritual coping (Lelorain, Tessier, Florin, \& Bonnaud-Antignac, 2012; Sears, Stanton, \& Danoff-Burg, 2003), problem-focused active coping (Lelorain et al., 2012; Scrignaro, Barni, \& Magrin, 2011; Widows, Jacobsen, Booth-Jones, \& Fields, 2005), and positive reframing (Schroevers, Helgeson, Sanderman, \& Ranchor, 2010; Thornton \& Perez, 2006). Use of both emotion and problem-based coping to cope with stress resulting from HIV infection was revealed in an Iranian study (Mahmoudi, Dehdari, Shojaeezadeh, \& Abbasian, 2015).

In turn, the application of avoidant coping strategies seems to foster the development of negative effects of experienced trauma. Coping strategies such as denial and behavioral disengagement were positively correlated with PTSD and allowed its symptoms to be predicted (Juczyński \& Ogińska-Bulik, 2009a). Avoidant coping was also positively associated with PTSD symptoms in a group of women who were victims of domestic abuse in childhood and people who had been burnt (Lawrence \& Fauerbach, 2003; Street, Gibson, \& Holohan, 2005).

Not many studies have been conducted with an aim to explain the role of coping strategies in posttraumatic adaptation among HIV+ patients. Rzeszutek, Oniszczenko, and Firląg-Burkacka (2012) point to emotion-focused coping, which had the greatest effect on intensity of trauma within such a group. In turn, Lawrence and Fauerbach (2003) indicate the importance of avoidant coping in PTSD.

The significance of adaptive coping strategies in the process of positive posttraumatic changes is highlighted by Tedeschi and Calhoun's model of posttraumatic growth $(1996,2004)$ and has been confirmed by the meta-analysis of the research results (Helgeson, Reynolds, \& Tomich, 2006; Linley \& Joseph, 2004; Prati \& Pietrantoni, 2009; Rajandram, Jenewein, McGrath, \& Zwahlen, 2011). Bussel and Naus's research (2010) examining women suffering from breast cancer demonstrated the predictive role of religious coping, acceptance and positive revaluation strategies. Schmidt, Blank, Bellizzi, and Park (2012) found that the strategies of active coping, positive reframing and religious beliefs contributed to posttraumatic growth (PTG) in cancer patients. Planning, seeking emotional/instrumental support and turning to religion also allow for prediction of positive consequences of HIV infection (Lelorain et al., 2012; Sears et al., 2003; Taylor \& Armor, 1996).

Polish research conducted among a group of emergency care workers demonstrated that in terms of the occurrence of positive effects of experienced traumatic events, turning to religion has been deemed the most conducive strategy. It was to be the main predictor of PTG (Ogińska-Bulik, 2014).

Moreover, the research indicated that the same strategies may be associated with both negative and positive effects deriving from a traumatic experience (Park, Aldwin, Fenster, \& Snyder, 2008; Pooley, Cohen, O'Connor, \& Taylor, 2013). The limited data and the complexity of the question - what are the consequences of experienced traumatic events and the ways of coping applied by HIV+ individuals? - constituted the premise for undertaking the present study.

The purpose of the research was to establish the role of stress coping strategies in the occurrence 
of negative (PTSD) and positive (PTG) effects of trauma related to HIV infection. It was hypothesized that HIV+ individuals suffer from symptoms of PTSD to a high extent, but also reveal positive changes, expressed as posttraumatic growth. Three main research questions were asked:

- Which of the coping strategies are the main ones in the research sample?

- Do coping strategies relate to PTSD symptoms and PTG intensity?

- Which of the analyzed coping strategies allow for prediction of PTSD and PTG?

\section{PARTICIPANTS AND PROCEDURE}

The study was conducted in the group of HIV+ individuals who assigned themselves for therapy conducted in the Voivodeship Drug Abuse Outpatient Center, members of the ECO School of Life, as well as members of the support group for people struggling with HIV in a city in central Poland. The participants were informed prior to completing the questionnaire that the forms are anonymous and that they are entitled to refuse to fill them in. Moreover, it was clearly expressed that completing it is equivalent to consenting to take part in the research, whose results will be used for scientific purposes exclusively. The study was approved by the appropriate Bioethics Commission.

From a group of $120 \mathrm{HIV}+$ adults only 64 measurement sets were included in the analysis. Forty-seven (39.00\%) people refused to participate in the research, and $9(7.50 \%)$ filled in the questionnaires incorrectly. So, the study group included 25 women $(39.10 \%)$ and 39 men $(60.90 \%)$. Participants' age ranged from 20 to 59 years $(M=38.20, S D=9.10)$. Almost half of those examined $(43.80 \%, n=28)$ declared that the infection took place over 5 years ago; 18 respondents $(28.10 \%)$ were infected within the past 2-5 years, 13 respondents $(20.30 \%)$ between 2 years and one year ago, and 5 respondents $(7.80 \%)$ within the last year. Four of the respondents became ill with AIDS.

The study applied three questionnaires based on a self-report method. All demographic information was gathered with the following questionnaires.

The Impact of Event Scale-Revised (IES-R) was developed by Weiss and Marmar (1997). It contains 22 statements (e.g., "Any reminder brought back feelings about it") and takes into account three dimensions of PTSD: intrusions, hyperarousal and avoidance. The Polish adaptation of this tool prepared by Juczyński and Ogińska-Bulik (2009a) was used in the study. The scale has good psychometric parameters. Internal consistency measured by Cronbach's $\alpha$ coefficient is .92 .

The Posttraumatic Growth Inventory (PTGI) was developed by Tedeschi and Calhoun's (1996). It contains 21 statements describing various posi- tive changes occurring as a result of a stressful experience (e.g. "I changed my priorities about what is important in life"). The response scale ranges from 0 to 5 . The Polish adaptation of this tool prepared by Ogińska-Bulik and Juczyński (2010), which was used in the study, measures four dimensions: changes in self-perception, changes in relations with others, greater appreciation of life and spiritual changes. The tool has obtained satisfactory psychometric properties. Cronbach's $\alpha$ is .93 (for each factor from .63 to .87), which is slightly higher than that for the original version.

The Coping Inventory - Mini-Cope, developed by Carver (1997), is a shortened version of the Coping Orientations to Problems Experienced. The Polish adaptation of the tool (Juczyński \& Ogińska-Bulik, 2009b), which was used in the study, includes 28 statements (e.g., "I turned to work or other substitute activities to take my mind off things"). MiniCope consists of 14 coping strategies: active coping, planning, positive reframing, acceptance, sense of humor, turning to religion, seeking emotional support, seeking instrumental support, self-distraction, denial, venting, substance use, behavioral disengagement, and self-blame. The tool has obtained satisfactory psychometric parameters (Cronbach's $\alpha$ indicator ranging from .62 for venting strategy to .89 for turning to religion). The tool used in the study measured strategies for coping with HIV infection.

\section{RESULTS}

The analysis of the data provided by the study consisted of several steps. First, means of PTSD and PTG were calculated. Sex, age of the participants and time since HIV diagnosis were also taken into account. Subsequently, the relationship between PTSD, PTG and coping strategies was investigated and it was established which stress coping strategies allow for prediction of PTSD and PTG. Since the distributions (measuring by the Kolmogorov-Smirnov test) of the considered variables were normal, parametric tests were used in the analysis. To determine the differences between the mean values Student's $t$-test was used and the relations between the variables were established with the Pearson correlation coefficient. In order to find the predictors of PTSD and PTG, regression analysis was used (the forward stepwise version). The calculations were performed with the STATISTICA software. Means and standard deviations of PTSD and PTG are presented in Table 1.

The IES-R scores were divided by the number of statements attributed to them (overall: $M=1.93$, $S D=1.16$, intrusion: $M=2.09, S D=1.24$, hyperarousal: $M=2.09, S D=1.24$, avoidance: $M=1.92, S D=0.98$, which did not differ statistically significantly) and were referenced to the 1.50 points limit es-
PTSD and PTG in HIV-infected patients - the role of coping strategies 
Table 1

Means and standard deviations for PTSD and PTG

\begin{tabular}{lcrrr}
\hline Variables & $M$ & $S D$ & $\min$ & $\max$ \\
\hline PTSD - general score & 43.56 & 22.26 & 0 & 81 \\
Intrusion & 15.44 & 9.30 & 0 & 36 \\
Hyperarousal & 14.66 & 8.69 & 0 & 28 \\
Avoidance & 13.47 & 6.90 & 0 & 26 \\
PTG - general score & 59.64 & 22.78 & 0 & 105 \\
Changes in self-perception & 24.61 & 10.79 & 0 & 45 \\
Changes in relations with others & 20.28 & 8.95 & 0 & 35 \\
Appreciation of life & 10.36 & 3.66 & 0 & 15 \\
Spiritual changes & 4.39 & 3.37 & 0 & 10 \\
\hline
\end{tabular}

Note. PTSD - posttraumatic stress disorder, PTG - posttraumatic growth.

tablished for the scale. According to this criterion (Juczyński \& Ogińska-Bulik, 2009a) $50.00 \%$ of patients exhibited at least moderate symptoms of PTSD (one participant did not report any negative change).

The average result of the PTG total score obtained a value of 5 sten. According to the sten scale standards (Ogińska-Bulik \& Juczyński, 2010), low scores were obtained by $42.20 \%$ of the respondents (one person did not notice any positive change), average results were observed in $28.10 \%$ and high in $29.70 \%$ of patients. More detailed analysis of the results (gained by dividing scale results by the number of items which contribute towards them) revealed that the HIV+ group shows a significantly greater change $(p<.010)$ in terms of appreciation of life $(M=3.45$, $S D=1.21$ ) than in other areas of growth (changes in self-perception: $M=2.73, S D=1.19$, changes in relations to others: $M=2.89, S D=1.27$, spiritual changes: $M=2.19, S D=1.12$ ).

Sex and age do not affect positive and negative effects of trauma. Time since diagnosis does not affect the severity of post-traumatic positive changes, but differentiates the level of PTSD symptoms (shorter [<5 years]: $M=49.42, S D=17.68$, longer: $M=36.04$, $S D=25.43, t=2.37, p<.050)$.

The most frequently used coping strategies among respondents were: acceptance $(M=4.22, S D=1.67)$, self-blame $(M=3.84, S D=1.84)$, active coping $(M=3.83, S D=1.56)$ and planning $(M=3.75$, $S D=1.78)$. Respondents least frequently used sense of humor $(M=2.17, S D=1.81)$ and turning to religion $(M=2.42, S D=2.26)$. Other strategies are used in an average degree (positive reframing: $M=3.08, S D=1.89$, seeking emotional support: $M=3.36, S D=1.76$, seeking instrumental support: $M=3.40, S D=1.85$, behavioral disengagement: $M=2.76, S D=2.12$, denial: $M=2.76, S D=2.12$, venting: $M=3.43, S D=1.82$, substance use: $M=3.23, S D=2.46$, self distraction: $M=2.68, S D=1.82$ ).
In order to answer the research question regarding the relationship between PTSD, PTG and coping strategies, correlation analysis was performed. The correlation coefficients are presented in Table 2.

The more frequently respondents used active coping strategies, self-distraction, self-blame, denial, venting and behavioral disengagement, the higher was the level of PTSD symptoms. These relationships apply to all symptoms of PTSD.

Seeking emotional support constitutes the strategy which is the most closely related to the posttraumatic growth level. The strategies of acceptance and turning to religion are also associated with PTG. Acceptance positively correlates with changes in self-perception and appreciation of life, while turning to religion correlates with changes in the spiritual sphere. Moreover, it is worth noting that along with increased frequency of the turning to religion strategy, the symptoms of avoidance intensify. A similar relationship was identified between behavioral disengagement, which belongs to avoidant strategies, and spiritual growth. However, it should be noted that the data received indicate weak and moderate relationships between the variables.

The last step of the analysis uses the linear regression method to determine which coping strategies allow for prediction of PTSD and PTG among the HIV+ group (Table 3).

Seven coping strategies (active coping, denial, venting, seeking emotional support, self-blame, self-distraction, behavioral disengagement), with Pearson's correlation coefficient significant at the level of at least $p<.010$, were entered as independent variables. Among the PTSD predictors, in a model explaining $37.00 \%$ of the variance of the dependent variable, there were three coping strategies. Active coping explains $23.00 \%$, denial $10.00 \%$, and self-blame $4.00 \%$ of the variance of PTSD. The more often they were used the higher was the level of PTSD. 
Table 2

Correlation coefficients between posttraumatic stress disorder, posttraumatic growth and coping strategies

\begin{tabular}{|c|c|c|c|c|c|c|c|c|c|}
\hline $\begin{array}{l}\text { Coping } \\
\text { strategies }\end{array}$ & $\begin{array}{l}\text { PTSD - } \\
\text { total }\end{array}$ & $\begin{array}{l}\text { Intru- } \\
\text { sion }\end{array}$ & $\begin{array}{l}\text { Hyper- } \\
\text { arousal }\end{array}$ & $\begin{array}{l}\text { Avoid- } \\
\text { ance }\end{array}$ & $\begin{array}{l}\text { PTG - } \\
\text { total }\end{array}$ & $\begin{array}{l}\text { Changes } \\
\text { in } \\
\text { self-per- } \\
\text { ception }\end{array}$ & $\begin{array}{c}\text { Chang- } \\
\text { es in } \\
\text { rela- } \\
\text { tions } \\
\text { with } \\
\text { others } \\
\end{array}$ & $\begin{array}{l}\text { Appre- } \\
\text { ciation } \\
\text { of life }\end{array}$ & $\begin{array}{c}\text { Spir- } \\
\text { itual } \\
\text { chang- } \\
\text { es }\end{array}$ \\
\hline $\begin{array}{l}\text { 1. Active } \\
\text { coping }\end{array}$ & $.48^{* * *}$ & $.41^{* *}$ & $.48^{* * *}$ & $.41^{* *}$ & .03 & .05 & .02 & .09 & -.12 \\
\hline 2. Planning & .25 & .11 & $.27^{*}$ & $.30^{*}$ & .19 & .22 & .13 & .11 & .10 \\
\hline $\begin{array}{l}\text { 3. Positive } \\
\text { reframing }\end{array}$ & .10 & .03 & .13 & .13 & .23 & $.26^{*}$ & .12 & .19 & .21 \\
\hline 4. Acceptance & -.16 & -.20 & -.16 & -.03 & $.29^{*}$ & $.32^{* *}$ & .16 & $.33^{* *}$ & .12 \\
\hline $\begin{array}{l}\text { 5. Sense of } \\
\text { humor }\end{array}$ & .05 & -.06 & .06 & .18 & .15 & .15 & .09 & .06 & .21 \\
\hline $\begin{array}{l}6 . \text { Turning to } \\
\text { religion }\end{array}$ & .19 & .04 & .16 & $.38^{* *}$ & $.26^{*}$ & .16 & .13 & .20 & $.62^{* * *}$ \\
\hline $\begin{array}{l}\text { 7. Seeking } \\
\text { emotional } \\
\text { support }\end{array}$ & .13 & .14 & .10 & .10 & $.46^{* * *}$ & $.41^{* *}$ & $.46^{* * *}$ & $.38^{* *}$ & .13 \\
\hline $\begin{array}{l}\text { 8. Seeking } \\
\text { instrumental } \\
\text { support }\end{array}$ & $.30^{*}$ & .25 & .24 & $.31^{*}$ & .21 & .21 & .20 & .14 & .02 \\
\hline $\begin{array}{l}\text { 9. Self- } \\
\text { distraction }\end{array}$ & $.35^{* *}$ & $.25^{*}$ & $.33^{* *}$ & $.38^{* *}$ & .18 & .17 & .18 & .24 & -.01 \\
\hline 10. Denial & $.46^{* * *}$ & $.43^{* * *}$ & $.39^{* *}$ & $.43^{* * *}$ & .09 & .05 & .07 & .07 & .10 \\
\hline 11. Venting & $.42^{* *}$ & $.38^{* *}$ & $.32^{*}$ & $.45^{* * *}$ & .02 & .05 & -.01 & .08 & -.09 \\
\hline $\begin{array}{l}\text { 12. Substance } \\
\text { use }\end{array}$ & .14 & .10 & .12 & .17 & -.10 & -.06 & -.04 & -.21 & -.18 \\
\hline $\begin{array}{l}\text { 13. Behavioral } \\
\text { disengagement }\end{array}$ & $.40^{* *}$ & $.27^{*}$ & $.37^{* *}$ & $.47^{* * *}$ & .04 & -.03 & .05 & -.01 & $.26^{*}$ \\
\hline 14. Self-blame & $.42^{* * *}$ & $.30^{*}$ & $.39^{* * *}$ & $.47^{* *}$ & .18 & .11 & .19 & .19 & .10 \\
\hline
\end{tabular}

Note. ${ }^{*} p<.05,{ }^{* *} p<.01,{ }^{* *} p<.001$; PTSD - posttraumatic stress disorder, PTG - posttraumatic growth.

Seeking emotional support strategy was found to be the only significant predictor of PTG $(21.00 \%$ of variance explained). The more often HIV+ subjects use it, the higher growth they experience.

Predictors for particular PTSD symptoms were also tested. The first symptom of the IES-R, intrusion, is explained by denial $\left(\beta=.32, R^{2}=.18\right)$ and active coping $\left(\beta=.30, R^{2}=.08\right)$ - the more often respondents use these strategies, the greater is the severity of the intrusion, but denial has greater predictive power. For the second symptom of PTSD hyperarousal - regression analysis also showed two predictors, which together explain $27.00 \%$ of the variance. Active coping $\left(\beta=.36, R^{2}=.20\right)$ explains $20.00 \%$ and self-blame $\left(\beta=.21, R^{2}=.07\right) 7.00 \%$ of the variance of this variable. Three strategies - selfblame $\left(\beta=.28, R^{2}=.22\right)$, self-distraction $(\beta=.26$, $\left.R^{2}=.09\right)$ and venting $\left(\beta=.26, R^{2}=.05\right)-$ allow for the prediction of avoidance symptoms, explaining together $36 \%$ of the variance.

Predictors for PTG factors were also tested. Changes in self-perception are explained by seeking emotional support $\left(\beta=.41, R^{2}=.17\right)$ and acceptance $\left(\beta=.27, R^{2}=.06\right)$, explaining together $23.00 \%$ of the variance. For changes in relations with others, as well as for appreciation of life, only the seeking emotional support strategy (respectively: $\beta=.46, R^{2}=.21$; $\beta=.39, R^{2}=.15$ ) has a predictive role. Turning to religion $\left(\beta=.68, R^{2}=.34\right)$ and behavioral disengagement $\left(\beta=.26, R^{2}=.06\right)$ allow for prediction of spiritual
PTSD and PTC in HIV-infected patients - the role of coping strategies 
Table 3

Predictors of posttraumatic stress disorder and posttraumatic growth (total)

\begin{tabular}{|c|c|c|c|c|}
\hline & $\beta$ & $B$ & $t$ & $p$ \\
\hline \multicolumn{5}{|l|}{ PTSD predictors } \\
\hline Active coping & .32 & 4.53 & 2.86 & .001 \\
\hline Denial & .26 & 2.77 & 2.29 & .020 \\
\hline Self-blame & .23 & 2.77 & 2.03 & .040 \\
\hline Constant value & & 7.91 & 1.15 & .250 \\
\hline \multicolumn{5}{|l|}{$R=.61, R^{2}=.37$} \\
\hline \multicolumn{5}{|l|}{ PTG predictors } \\
\hline Seeking emotional support & .46 & 5.90 & 4.05 & $<.001$ \\
\hline Constant value & & 39.85 & 7.22 & $<.001$ \\
\hline$R=.46, R^{2}=.21$ & & & & \\
\hline
\end{tabular}

Table 4

Juxtaposition of PTSD and PTG predictors

\begin{tabular}{lc}
\hline Predictors & \\
\hline $\begin{array}{l}\text { PTSD - total: } \\
\text { Active coping } \\
\text { Denial }\end{array}$ & PTG - total: \\
Self-blame & \\
Intrusion: & Changes in self-perception: \\
$\begin{array}{l}\text { Denial } \\
\text { Active coping }\end{array}$ & Seeking emotional support \\
Hyperarousal: & Acceptance \\
Active coping & Changes in relations with \\
Self-blame & others: \\
Avoidance: & Seeking emotional support \\
Self-blame & Appreciation of life: \\
Self-distraction & Seeking emotional support \\
Venting &
\end{tabular}

Spiritual changes:

Turning to religion

Behavioral disengagement

Note. PTSD - posttraumatic stress disorder, PTG - posttraumatic growth.

changes. Results for all PTSD and PTG predictors are presented in Table 4.

\section{DISCUSSION}

The data obtained in the course of the analysis have shown that half of the examined HIV+ patients express a moderate or high intensity of PTSD symptoms. The result is slightly higher than the results achieved by examining HIV+ patients in Gambia
(Peterson, Togun, Klis, Menten, \& Colebunders, 2012), but similar to the results of examining women in Rwanda (Cohen et al., 2009) as well as the USA clinics' patients (Martinez et al., 2002); however, we should be aware of cultural differences.

Positive posttraumatic changes among HIV + patients were also noted - medium and high PTG intensity was reported among the majority of the respondents. The results are in accordance with Milam's (2006) research results, which confirmed that $57.00 \%$ of HIV-infected patients experienced PTG at a moderate level. The results obtained for the examined HIV+ group are similar to those obtained for women after mastectomy and patients with cardiovascular diseases (Ogińska-Bulik \& Juczyński, 2010). The examined individuals living with HIV experienced more positive changes of life appreciation when compared to the remaining PTG areas. This implies that in spite of experiencing negative consequences of the infection, the examined individuals undergo a transformation process associated with the posttraumatic growth.

Neither sex nor age of the examined HIV+ persons influences the level of PTSD and PTG. The results are not consistent with data obtained in another study of HIV-positive individuals, which revealed that women scored higher on some PTSD symptoms - intrusion/ arousal and one PTG scale - spiritual changes (Rzeszutek et al., 2016). The time since the HIV diagnosis does not impact the PTG level, but it diversify the level of PTSD symptoms. The PTSD level is slightly higher among the people who have been diagnosed with HIV in a shorter period of time (less than 5 years since the moment of performing the research). In the case of the study group, the passage of time seems to alleviate the PTSD symptoms.

Significant correlations between the positive as well as negative HIV infection effects and coping 
strategies were found. The higher the frequency of the avoidance-focused strategies, such as denial, venting, behavioral disengagement, self-blame and self-distraction, the more intense were the PTSD symptoms. Moreover, what is striking, the strategy of active coping positively correlated with all the dimensions and the overall results of IES-R and was found to be predictor of the PTSD symptoms (total results), intrusion and hyperarousal.

With regards to active coping, a negative relationship with PTSD symptoms was expected. This association was revealed in a study conducted by Rzeszutek et al. (2012). In the case of the examined HIV-positive individuals, actions undertaken with the purpose of removing or decreasing the influence of a stressor or its effects increase the intensity of the PTSD symptoms. This might be explained by the fact that in order to plan and then undertake actions related to situation improvement, the current state needs to be deemed disadvantageous. Yet, doing so requires engagement of cognitive analysis of the past events. Such a target-aimed strategy, in spite of engaging mainly behavioral strategies (Heszen, 2012), takes into account cognitive analysis as well. As a consequence, it might elicit recurring images, thoughts or reflections associated with the experienced event (intrusions), avoidance of thoughts, feelings, stimuli, alienation (avoidance), psychophysiological hyperactivity and intensified vigilance (hyperarousal), which all account for the PTSD. It resembles the pattern of a vicious circle: the HIV+ patients make attempts to improve their situation; yet, these attempts are based on cognitive processes eliciting the PTSD symptoms. It cannot be excluded that they may as well generate additional stress related to the helplessness of controlling the current state. The active coping strategy could also be connected to ruminations, especially deliberate, associated with consideration of a possible solution to the situation. On the other hand, ruminations (intrusive, in particular) are closely related to the intrusion symptoms (Cann et al., 2011). Finally, it might be linked to the specificity of the experienced event, namely, the HIV infection. Therefore, establishing the direction of the relationship between the strategy of active coping and the PTSD symptoms would require further studies.

Apart from active coping, the significance of such strategies as denial, self-blame, self-distraction and venting should be noted. Their application increases the PTSD symptoms. These results are in line with the results from longitudinal studies conducted among women with breast cancer (Bussel \& Naus, 2010). Such strategies as denial, self-distraction, venting and turning to religion were also related to PTSD symptoms in a group of firefighters who experienced trauma due to their profession (Ogińska-Bulik \& Langer, 2007).

The role of avoidant strategies in maintenance of PTSD is stressed by Ehlers and Clark (2000). The au- thors argue that this type of coping prevents adaptive modification of negative appraisal and vivid emotional traumatic memory, which leads to the development of PTSD.

Among the HIV-infected individuals, the emotion-focused strategies, especially the one of seeking emotional support, seem to be particularly significant in order for the positive posttraumatic changes to emerge. The strategy was positively correlated with nearly every dimension within the scope of PTG (excluding spiritual changes), and appeared to be the leading predictor of the overall PTG results, as well as the changes in relations with others and appreciation of life. The importance of the strategy of seeking emotional support for the positive posttraumatic changes to take place has been confirmed in research conducted among patients with oncological diseases (Morris, Shakespeare-Finch, \& Scott, 2007; Park et al., 2008) as well as among medical rescue workers who experienced trauma due to their profession (Ogińska-Bulik, 2014). Seeking support and understanding others seems to be particular important among HIV+ individuals. They are a highly stigmatized group, mainly due to the form of transmission of the virus (Schweitzer, Mizwa, \& Ross, 2010). Support received from others may have an advantageous impact on the emergence of positive emotions, or at least reduce the negative ones, which is of pivotal importance in the process of posttraumatic growth (Heszen, 2012).

Acceptance is another strategy related to the occurrence of positive posttraumatic changes, as was confirmed by other researchers (Hallam \& Morris, 2013; Helgeson et al., 2006; Linley \& Joseph, 2004; Prati \& Pietrantoni, 2009; Rajandram, Jenewein, McGrath, \& Zwahlen, 2011). For the majority of people, being diagnosed with the HIV virus is shocking. The cognitive processing of such information and acceptance of a changed state allow for re-discovering of one's life's value. Moreover, the data obtained from the research has indicated that spiritual changes are of pivotal importance as well. The significant role of the strategy in the process of positive posttraumatic changes has been confirmed by studies conducted among people suffering from cancer (Lelorain et al., 2012; Sears et al., 2003) and a group of paramedics (Ogińska-Bulik, 2014).

The studies' results have shown that more coping strategies are related to PTSD than PTG. Most of them are focused on avoiding stressful situations. There are no common strategies which on the one hand would reduce the severity of PTSD symptoms, and on the other would increase PTG.

Attention should be drawn to the restrictions of the research. The group of HIV-infected people taking part in the studies was not large. There have been no other negative traumatic experiences analyzed, apart from the HIV infection, which could have oc-
PTSD and PTG in HIV-infected patients - the role of coping strategies 
curred and influenced the emergence of negative and positive changes, especially due to the fact that the majority of respondents had been infected with the HIV virus five years before the study was conducted. Mode of transmission and medical treatment were not analyzed. The assessment of the experienced traumatic events' effects was performed using a self-report method. The IES-R, which is a tool used in the study, serves for the purpose of posttraumatic stress symptoms measurement; it does not constitute Nina Ogińska-Bulik, Klaudia Kraska a clinical PTSD diagnosis. Thus, the influence of social approval variable cannot be excluded. Furthermore, the studies were cross-sectional, which does not allow cause-effect relationships to be explained.

Despite the aforementioned limitations, it should be stressed that the results of the research provide new information in the area of studies on the consequences of traumatic experiences and their relations with coping. They confirm that avoidance-focused coping strategies are related to PTSD, and indicate that emotion-focused strategies are associated with posttraumatic growth.

The results are assigned to the new psychological trend, namely, positive psychology, devoted to the favorable traits of a human being. These results might be used in practice or as inspiration for further research. It would be worth including in the subsequent studies the role of cognitive processes, especially ruminations, which are relevant for both positive and negative consequences of the traumatic experiences. Moreover, it could be valuable to investigate the influence of the manner of HIV infection, based on PTSD and PTG.

\section{CONCLUSIONS}

Coping strategies play a significant role in the occurrence of negative and positive effects of experienced traumatic events. Based on the conducted study, the following conclusions can be drawn:

- coping strategies play a diverse role in the occurrence of PTSD and PTG;

- avoidance-focused strategies seem to favor development of PTSD symptoms;

- emotion-focused strategies, especially seeking emotional support, foster the occurrence of positive posttraumatic changes.

\section{RefERENCES}

AIDS National Center in Poland. (2012). Sytuacja epidemiologiczna HIV w Polsce na koniec 2012 [HIV epidemiology in Poland for 2012]. Available from: www.aids.gov.pl

Breet, E., Kagee, A., \& Seedat, S. (2014). HIV-related stigma and symptoms of posttraumatic stress dis- order and depression in HIV individuals. Does social support play a mediating or moderating role? AIDS Care, 26, 947-951.

Bussel, V., \& Naus, M. (2010). A longitudinal investigation of coping and posttraumatic growth in breast cancer survivors. Journal of Psychosocial Oncology, 28, 61-78.

Cann, A., Calhoun, L. G., Tedeschi, R. G., Triplett, K. N., Vishnevsky, T., \& Lindstrom, C. M. (2011). Assessing posttraumatic cognitive processes: the Event Related Rumination Inventory. Anxiety, Stress \& Coping, 24, 137-156.

Carver, C. (1997). You want to measure coping but your protocol's too long: consider the brief COPE. International Journal of Behavioral Medicine, 4, 92-100.

Cohen, M. H., Fabri, M., Cai, X., Shi, Q., Hoover, D. R., Binagwaho, A., Culhane, M. A., Mukanyonga, H., Karegeya, D. K., \& Anastos, K. (2009). Prevalence and predictors of posttraumatic stress disorder and depression in HIV-infected and at-risk Rwandan women. Journal of Womens Health, 18, 1783-1791.

Ehlers, A., \& Clark, D. M. (2000). A cognitive model of posttraumatic stress disorder. Behaviour Research and Therapy, 38, 319-345.

Hallam, W., \& Morris, R. (2013). Post-traumatic growth in stroke carers: A comparison of theories. British Journal of Health Psychology, 19, 619-635. doi: 10.1111 /bjhp. 12064

Helgeson, V., Reynolds, K., \& Tomich, P. (2006). A meta-analytic review of benefit finding and growth. Journal of Consulting and Clinical Psychology, 74, 797-816.

Heszen, I. (2012). Problemy zdrowotne i radzenie sobie z nimi - od zaprzeczania do emocji pozytywnych [Health problems and coping with them - from denial to positive emotions]. In N. OgińskaBulik \& J. Miniszewska (eds.), Zdrowie w cyklu życia człowieka [Health in man's life cycle] (pp. 181-197). Łódź: University Press.

Israelski, D. M., Prentiss, D. E., Lebega, S., Balmas, G., Garcia, P., Muhammad, M., Cummings, S., \& Koopman, C. (2007). Psychiatric co-morbidity in vulnerable populations receiving primary care for HIV/AIDS. Aids Care, 19, 220-225.

Juczyński, Z., \& Ogińska-Bulik, N. (2009a). Pomiar zaburzeń po stresie traumatycznym - polska wersja zrewidowanej Skali Wpływu Zdarzeń [Measurement of post-traumatic stress disorder - Polish version of Impact Event Scale-Revised]. Psychiatria, 6, 15-25.

Juczyński, Z., \& Ogińska-Bulik, N. (2009b). Narzędzia pomiaru stresu i radzenia sobie ze stresem [Measurement tools of stress and coping with stress]. Warszawa: Pracownia Testów Psychologicznych.

Lawrence, J. W., \& Fauerbach, J. A. (2003). Personality, coping, chronic stress, social support and PTSD symptoms among adults burn survivors: 
a path analysis. Journal of Burn Care \& Rehabilitation, 24, 63-72.

Lelorain, S., Tessier, P., Florin, A., \& Bonnaud-Antignac, A. (2012). Posttraumatic growth in long term breast cancer survivors: relation to coping, social support and cognitive processing. Journal of Health Psychology, 17, 627-639.

Linley, P. A., \& Joseph, S. (2004). Positive change following trauma and adversity: A review. Journal of Traumatic Stress, 17, 11-21.

Mahmoudi, M., Dehdari, T., Shojaeezadeh, D., \& Abbasian, L. (2015). Coping with stress strategies in HIV-infected Iranian patients. Journal of the Association of Nurses in AIDS Care, 26, 464-471.

Martinez, A., Israelski D., Walker, C., \& Koopman, C. (2002). Posttraumatic stress disorder in women attending human immunodeficiency virus outpatient clinics. AIDS Patient Care STDS, 16, 283-291.

Milam, J. E. (2004). Posttraumatic growth among HIV/AIDS patients. Journal of Applied Social Psychology, 34, 2353-2376.

Milam, J. E. (2006). Posttraumatic growth and HIV disease progression. Journal of Consulting \& Clinical Psychology, 74, 817-827.

Morris, B., Shakespeare-Finch, J., \& Scott, J. (2007). Coping process and dimensions of posttraumatic growth. Australasian Journal of Disaster and Trauma Studies, 1, 1-12.

Nightingale, V. R., Sher, T. G., \& Hansen, N. B. (2013). The impact of receiving an HIV diagnosis and cognitive processing on psychological distress and posttraumatic growth. Journal of Traumatic Stress, 23, 452-460.

Ogińska-Bulik, N. (2014). Rola strategii radzenia sobie ze stresem w rozwoju po traumie u ratowników medycznych [The role of coping strategies in posttraumatic growth in medical rescue workers]. Medycyna Pracy, 65, 209-217.

Ogińska-Bulik, N. (2016). Ruminacje a negatywne i pozytywne skutki traumy u zakażonych HIV [Rumination and negative and positive effects of trauma in HIV-infected]. Psychiatria, 13, 8-16.

Ogińska-Bulik, N., \& Juczyński, Z. (2010). Rozwój potraumatyczny - charakterystyka i pomiar [Posttraumatic growth - characteristic and measurement]. Psychiatria, 7, 129-142.

Ogińska-Bulik, N., \& Langer, I. (2007). Osobowość typu D i strategie radzenia sobie ze stresem a nasilenie objawów PTSD w grupie strażaków [Type D personality, coping with stress and intensity of PTSD symptoms in firefighters]. Medycyna Pracy, 58, 307-316.

Olley, B. O., Zeier, M. D., Seedat, S., \& Stein, D. J. (2005). Post-traumatic stress disorder among recently diagnosed patients with HIV/AIDS in South Africa. AIDS Care, 17,550-557. doi: 10.1080/09540120412331319741

Park, C. L., Aldwin, C. M., Fenster, J. R., \& Snyder, L. B. (2008). Pathways to posttraumatic growth versus posttraumatic stress: coping and emotional reactions following the September 11, 2001 terrorist attacks. American Journal of Orthopsychiatry, 78, 300-312.

Peterson, K., Togun, T., Klis, S., Menten, J., \& Colebunders, R. (2012). Depression and posttraumatic stress disorder among HIV-infected Gambians on antiretroviral therapy. AIDS Patients Care STDs, 26, 589-596.

Pooley, J. A., Cohen, L., O’Connor, M., \& Taylor, M. (2013). Posttraumatic stress and posttraumatic growth and their relationship to coping and self-efficacy in Northwest Australian cyclone communities. Psychological. Trauma: Theory, Research, Practice, and Policy, 5, 392-399.

Prati, G., \& Pietrantoni, L. (2009). Optimism, social support and coping strategies contributing to posttraumatic growth: A meta-analysis. Journal of Loss and Trauma, 14, 364-388.

Rajandram, R. K., Jenewein, J., McGrath, C., \& Zwahlen, R. A. (2011). Coping processes relevant to posttraumatic growth: an evidence-based review. Support Care Cancer, 19, 583-589.

Rzeszutek, M., Oniszczenko, W., \& Firląg-Burkacka, E. (2012). Temperament traits, coping style and trauma symptoms in HIV men and women. AIDS Care, 24, 1150-1154.

Rzeszutek, M., Oniszczenko, W., \& Firląg-Burkacka, E. (2016). Gender differences in posttraumatic stress symptoms and the level of posttraumatic growth among Polish sample of HIV-positive individuals. AIDS Care, 28, 1411-1415. doi: 10.1080/09540121.2016.1182615

Schmidt, S., Blank, T., Bellizzi, K., \& Park, C. (2012). The relationship of coping strategies, social support, and attachment style with posttraumatic growth in cancer survivors. Journal of Health Psychology, 17, 1033-1040.

Schroevers, M. J., Helgeson, V. S., Sanderman, R., \& Ranchor, A. V. (2010). Type of social support matters for prediction of posttraumatic growth among cancer patients. Psychooncology, 19, 46-53.

Schweitzer, A., Mizwa, M. B., \& Ross, M. W. (2010). Psychosocial aspects of HIV/AIDS: adults. In Baylor International Pediatric AIDS Initiative and Baylor College of Medicine (eds.), HIV Curriculum for the Health Professional (pp. 334-349). Baylor College of Medicine.

Scrignaro, M., Barni, S., \& Magrin, M. E. (2011). The combined contribution of social support and coping strategies in predicting post-traumatic growth: a longitudinal study on cancer patients. Psychooncology, 20, 823-831. doi: 10.1002/pon 1782 Sears, S. R., Stanton, A. L., \& Danoff-Burg, S. (2003). The yellow brick road and the emerald city: benefit finding, positive reappraisal coping, and posttraumatic growth in women with early-stage breast cancer. Health Psychology, 22, 487-496.
PTSD and PTG in HIV-infected patients - the role of coping strategies 
Sherr, L., Nagra, N., Kulubya, G., Catalan, J., Clucas, C., \& Harding, R. (2011). HIV infection associated post-traumatic stress disorder and post-traumatic growth - A systematic review. Psychology, Health \& Medicine, 16, 612-629.

Street, A. E., Gibson, L. E., \& Holohan, D. R. (2005). Impact of childhood traumatic events, trauma-related guilt, and avoidant coping strategies on PTSD symptoms in female survivors of domestic violence. Journal of Traumatic Stress, 18, 245-252.

Nina Ogińska-Bulik, Klaudia Kraska

Taylor, S. E., \& Armor, D. A. (1996). Positive illusions and coping with adversity. Journal of Personality, 64, 873-898.

Tedeschi, R. G., \& Calhoun, L. G. (1996). The Post-Traumatic Growth Inventory: Measuring the positive legacy of trauma. Journal of Traumatic Stress, 9, 455-471.

Tedeschi, R. G., \& Calhoun, L. G. (2004). Posttraumatic growth: Conceptual foundations and empirical evidence. Psychological Inquiry, 15, 1-8.

Tedstone, J. E., \& Tarrier, N. (2003). Posttraumatic stress disorder following medical illness and treatment. Clinical Psychology Review, 23, 409-448.

Thornton, A. A., \& Perez, M. A. (2006). Posttraumatic growth in prostate cancer survivors and their partners. Psychooncology, 15, 285-296.

UNAIDS - Joint United Nations Programme on HIV/ AIDS. Global report epidemiology slides. (2013). Available from: http://www.unaids.org/en/dataanalysis/knowyourepidemic/epidemiologypublications/

Updegraff, J. A., Taylor, S. E., Kemeny, M. E., \& Wyatt, G. E. (2002). Positive and negative effects of HIV infection in women with low socioeconomic resources. Personality and Social Psychology Bulletin, 28, 382-394.

Weiss, D., \& Marmar, C. (1997). The Impact of Event Scale - Revised. In J. Wilson \& T. Keane (eds.), Assessing psychological trauma and PTSD: A handbook for practitioners (pp. 399-411). New York: Guilford Press.

Widows, M. R., Jacobsen, P. B., Booth-Jones, M., \& Fields, K. K. (2005). Predictors of posttraumatic growth following bone marrow transplantation for cancer. Health Psychology, 24, 266-273. 